\title{
Adsorption Mechanisms of Dodecylbenzene Sulfonic Acid by Corn Straw and Poplar Leaf Biochars
}

\author{
Nan Zhao ${ }^{1,2}$, Xixiang Yang ${ }^{3}$, Jing Zhang ${ }^{4}$, Ling Zhu ${ }^{1}$ and Yizhong $\mathrm{Lv}^{1, *}$ \\ 1 College of Resources and Environmental Sciences, China Agricultural University, Beijing 100193, China; \\ zhaonan8@mail.sysu.edu.cn (N.Z.); zhuling@cau.edu.cn (L.Z.) \\ 2 Guangdong Provincial Key Lab of Environmental Pollution Control and Remediation Technology, \\ School of Environmental Science and Engineering, Sun Yat-sen University, Guangzhou 510275, China \\ 3 Department of Applied Chemistry, Graduate School of Engineering, Kyushu University, 744 Motooka, \\ Nishi-ku, Fukuoka 819-0395, Japan; qiqiang2010@yeah.net \\ 4 Department of Environmental Nano-Materials, Research Center for Eco-Environmental Sciences, \\ Chinese Academy of Sciences, Beijing 100085, China; jingzhang@rcees.ac.cn \\ * Correspondence: lyz@cau.edu.cn; Tel.: +86-106-273-1431
}

Received: 6 August 2017; Accepted: 19 September 2017; Published: 22 September 2017

\begin{abstract}
Biochar is an eco-friendly, renewable, and cost-effective material that can be used as an adsorbent for the remediation of contaminated environments. In this paper, two types of biochar were prepared through corn straw and poplar leaf pyrolysis at $300{ }^{\circ} \mathrm{C}$ and $700{ }^{\circ} \mathrm{C}(\mathrm{C} 300, \mathrm{C} 700, \mathrm{P} 300$, P700). Brunaer-Emmett-Teller $\mathrm{N}_{2}$ surface area, scanning electron microscope, elemental analysis, and infrared spectra were used to characterize their structures. These biochars were then used as adsorbents for the adsorption of dodecylbenzene sulfonic acid (DBSA). The microscopic adsorption mechanisms were studied by using infrared spectra, ${ }^{13} \mathrm{C}$-nuclear magnetic resonance spectra, and electron spin resonance spectra. The surface area and pore volume of C700 $\left(375.89 \mathrm{~m}^{2} / \mathrm{g}\right.$ and $0.2302 \mathrm{~cm}^{3} / \mathrm{g}$ ) were the highest among all samples. Elemental analysis results showed that corn straw biochars had a higher aromaticity and carbon to nitrogen $(\mathrm{C} / \mathrm{N})$ ratio than the poplar leaf biochars. High temperature caused the increase of carbon content and the decrease of oxygen content, which also gave the biochars a higher adsorption rate. Pseudo-second order kinetic provided a better fit with the experimental data. Adsorption isotherm experiments showed that the adsorption isotherm of C300 fit the linear model. For other biochars, the adsorption isotherms fitted Langmuir model. Biochars with high temperatures exhibited enhanced adsorption capacity compared with ones at low temperatures. The $q_{\max }$ values of biochars to DBSA followed the order of P700 > C700 > P300. The adsorption mechanisms were complex, including partition, anion exchange, the formation of $\mathrm{H}$ bonds, covalent bonds, and charge transfer. The adsorption by covalent bonding might be the key mechanism determining the adsorption capacity of P700.
\end{abstract}

Keywords: corn straw; poplar leaf; biochar; structural characteristics; adsorption mechanism

\section{Introduction}

Linear alkylbenzene sulfonates (LAS) are popularly used in detergents and cleaning products. They can cause environmental hazards after entering into surface waters by household and industrial sewage [1]. Some techniques have been applied for the removal of surfactants from water or soils. Adsorption is a superior method for water treatment or soil remediation due to its low cost, easy operation, and high efficiency. Mineral oxides, clays, activated carbon, and polymers can be used as the adsorbents for the adsorption of surfactants [2], but the sorption capacity of sodium dodecyl sulfate on Fluvisol soil was very low [3]. 
Renewable bioenergy technologies can convert biomass feedstock into biochar, accompanied with the production of bio-gas and bio-oil [4,5]. Biochar is a carbonaceous material created through thermal pyrolysis of biomass without oxygen condition. The yield of biochar will decrease in the pyrolysis process, due to the dehydration and thermal degradation of cellulose and lignin structures [6]. The type of feedstock and pyrolysis temperatures can also influence the physical, chemical and adsorption properties of biochars. Wheat straw biochar had higher carbon and nitrogen contents and lower ash materials, as compared with corn straw biochar [7]. Pine sawdust biochar also had a higher adsorption capacity than that of green waste and corncob biochars [8]. Higher pyrolysis temperature could cause the increase of $\mathrm{C}$ content and the adsorption affinity of organic contaminants on biochars. At the same time, $\mathrm{H}, \mathrm{O}, \mathrm{N}$ and $\mathrm{S}$ contents decreased $[9,10]$. Biochars have strong adsorption capacities for contaminants, such as carbaryl [11], naphthalene [9], fluoroquinolone antibiotics [12], hexavalent chromium [5], and so on. There is very little information on the adsorption properties of LAS on biochars.

Westall et al. had studied the sorption of LAS on the sediment materials, and the results showed that Freundlich and virial equations fitted the isotherms well [1]. The sorption mechanisms included hydrophobic interaction, specific chemical interaction, or electrostatic interaction. Sodium dodecyl sulfate could also be adsorbed by hydrophobic interaction with organic matter of the soil and by ligand exchange or electrostatic attraction with kaolinite [13]. Sodium dodecylbenzene sulfonate (SDBS) is an anionic surfactant that is used extensively worldwide. Many papers had reported its adsorption behaviors and adsorption mechanisms. It could be adsorbed onto the organophilic bentonites or activated carbon by the monolayer adsorption with a relatively fast process [14,15]. However, the adsorption of SDBS on kaolinite was a two-stage process with an apparent multilayer formation [16].

Dodecylbenzene sulfonic acid (DBSA) is the acid form of SDBS. DBSA could be adsorbed on humic acids (HAs) by $\mathrm{H}$ bonds, hydrophobic interactions, and electron donor-acceptor mechanisms. Alluvial soil HA had a higher sorption capacity than that of Mollisol soil HA [17]. The adsorption behaviors of DBSA on biochars have been seldom reported. Corn straw and poplar leaf are commonly seen in China, and they are attractive feedstocks for biochar production. Therefore, we chose corn straw and poplar leaf as the biomass feedstocks to produce biochars in this study. The objective of the study was to obtain a deeper investigation of the influence of the pyrolysis temperature and biomass feedstocks on the physicochemical properties of biochars, and the adsorption behaviors of DBSA on different types of biochars. Further, infrared (IR) spectra, ${ }^{13} \mathrm{C}$-nuclear magnetic resonance (NMR) spectra and electron spin resonance (ESR) spectra were applied to study the adsorption mechanisms. The application of ESR provides a new insight into the adsorption mechanism of DBSA on biochars.

\section{Materials and Methods}

\subsection{Materials}

Dodecylbenzene sulfonic acid (95\%) was purchased from TCI (TCI, Shanghai, China). Its critical micelle concentration (CMC) is $0.4134 \mathrm{~g} / \mathrm{L}$ [18]. The biomasses of corn straw and poplar leaf were collected from Inner Mongolia and Beijing, China. Before the pyrolysis, corn straw and poplar leaf were washed to remove the ash. Then, the dried biomass feedstocks were put into stainless steel reactors (cylindrically shaped with a height of $10.5 \mathrm{~cm}$ and an inner diameter of $7.5 \mathrm{~cm}$ ) and pyrolyzed in a Sx2-4-10 digital laboratory muffle furnace (Zhonghuan Lab Furnae Co., Ltd., Tianjin, China) at $300{ }^{\circ} \mathrm{C}$ and $700{ }^{\circ} \mathrm{C}$ for two hours with a heating rate of $10^{\circ} \mathrm{C} / \mathrm{min}$. These products were mixed with $1 \mathrm{M} \mathrm{HCl}$ and $3 \mathrm{M} \mathrm{HF}$ to remove the ash materials. After washing with deionized water, the corn straw biochar and poplar leaf biochar were crushed and sieved to $0.25 \mathrm{~mm}$. The obtained biochars were referred to as C300, C700, P300 and P700. HCl and HF (Sinopharm Chemical Reagent Co., Ltd., Shanghai, China) were all of analytical grade. 


\subsection{Test Method}

\subsubsection{Biochar Characterization}

Scanning electron microscope (SEM) images of the biochars were recorded by a Hitachi S- 4800 scanning microscope (Hitachi, Tokyo, Japan). The Brunauer-Emmett-Teller (BET) nitrogen specific surface areas of biochars were determined by $\mathrm{N}_{2}$ adsorption-desorption at $77 \mathrm{~K}$ with a Tristrar II 3020 surface area analyzer (Micromeritics, Norcross, GA, USA). The contents of C, N, and H were determined in a Vario EL III elemental analyzer (Elementar, GmbH, Hanau, Germany). The O content was calculated based on the equation: $\mathrm{O} \%=100 \%-\mathrm{C} \%-\mathrm{H} \%-\mathrm{N} \%-$ ash content. The micro IR spectra were recorded in the range of $4000-600 \mathrm{~cm}^{-1}$ with a resolution of $4 \mathrm{~cm}^{-1}$ using a Nicolet Nexus-470 FTIR spectrometer (Thermo Nicolet, San Diego, CA, USA). The solid-state ${ }^{13}$ C-NMR spectra were acquired on a Bruker DSX2300 spectrometer (Bruker, Faellanden, Switzerland) operated at 100.37 MHz. The sample was packed in a $4 \mathrm{~mm}$ rotor with a contact time of $3000 \mu \mathrm{s}$. The scan times were more than 20,000. ESR spectra were undertaken using a Bruker ESP300 spectrometer (Bruker BioSpin, Billerica, MA, USA) and operated at $100 \mathrm{kHz}$ modulation and $9.75 \mathrm{GHz}$ microwave frequency.

\subsubsection{Batch Adsorption Experiments}

The adsorption kinetics of DBSA at a constant concentration $(120 \mathrm{mg} / \mathrm{L}, 20 \mathrm{~mL})$ onto $60 \mathrm{mg}$ biochars were examined at different sampling times $(0,1,2,5,10,16,24,36,48,60$, and $72 \mathrm{~h})$. The temperature was $25 \pm 2{ }^{\circ} \mathrm{C}$. After shaking at the speed of $130 \mathrm{rpm}$, the solution was centrifuged at $5000 \mathrm{rpm}$ for $12 \mathrm{~min}$, and filtered through a $0.22 \mu \mathrm{m}$ membrane. The concentration of DBSA was measured at $223 \mathrm{~nm}$ using the UV757 spectrophotometer (Shanghai Accurate Scientific Instrument Co., Ltd., Shanghai, China). Each point containing the blank and control samples was conducted in triplicate.

Different concentrations of DBSA solution ( $15 \mathrm{mg} / \mathrm{L}-360 \mathrm{mg} / \mathrm{L}, 20 \mathrm{~mL}$ ) were mixed with $60 \mathrm{mg}$ biochars in a $50 \mathrm{~mL}$ flask and shaken for $48 \mathrm{~h}$ to reach adsorption equilibrium for obtaining the adsorption isotherms. Then the mixtures were treated as described above.

\subsubsection{Data Analysis}

The amount of DBSA adsorbed was calculated by the following equation:

$$
\begin{gathered}
q_{e}=V\left(C-C_{e}\right) / m \\
R \%=\left(C-C_{e} / C\right) \times 100 \%
\end{gathered}
$$

where $V$ is the volume of the solution $(\mathrm{mL}), C$ and $C_{e}$ are the initial and equilibrium concentrations $(\mathrm{mg} / \mathrm{L}), m$ is the weight of the biochars $(\mathrm{g})$, and $R \%$ represents the removal efficiency.

The relationships between the adsorption rate constants and the chemical compositions of biochars were examined using the Pearson correlation coefficient.

\section{Results and Discussion}

\subsection{Characteristics of Biochars}

C700 and P700 samples exhibited larger surface areas $\left(375.89 \mathrm{~m}^{2} / \mathrm{g}\right.$ and $\left.105.88 \mathrm{~m}^{2} / \mathrm{g}\right)$ and pore volumes $\left(0.2302 \mathrm{~cm}^{3} / \mathrm{g}\right.$ and $\left.0.0721 \mathrm{~cm}^{3} / \mathrm{g}\right)$ than that of C300 and P300. Corn straw biochars also had higher surface areas and pore volumes by comparing with that of poplar leaf biochars. The average pore sizes of the biochars ranged from 3.98-12.27 nm (Table 1). The SEM micrographs of the biochars were demonstrated in Figure 1. C300 and P300 samples had fewer pores and more smooth appearances. At low temperature, amorphous carbons were the main carbons, and pores were not well developed. C700 and P700 presented uniform tunneling macropore structures in Figure 1b,d. C700 also had some smaller pore structures inside the tunneling macropores. Due to the high temperature, the tunneling 
structures had been crushed. The adsorption and desorption isotherms for biochars are shown in Figure 2. The similar isotherms of C700 and P700 suggested that the adsorption of $\mathrm{N}_{2}$ on biochars may follow similar kinetics [19] because of their similar pore structures. For C300 as well as for P300, the isotherms are characteristic of non-porous materials or materials with large macropores, indicating no porous structure. The elemental compositions and atom ratios of biochars are shown in Table 2. The $\mathrm{C}$ contents and $\mathrm{C} / \mathrm{N}$ ratios of corn straw biochars were higher than those of poplar leaf biochars. The low ratios of $\mathrm{H} / \mathrm{C}(0.21$ and 0.38$)$ indicated the high aromatization of biochars [20], because some of the amorphous carbon would be transformed into aromatic carbon at $700{ }^{\circ} \mathrm{C}$ [21]. The $\mathrm{C}$ contents, ash materials, and $\mathrm{C} / \mathrm{N}$ ratios of the biochars were also greater at a higher pyrolyzing temperature. $\mathrm{O} / \mathrm{C}$ was indicative of surface hydrophilicity, and $(\mathrm{O}+\mathrm{N}) / \mathrm{C}$ was recognized as the indice of polarity [22,23]. $\mathrm{H}, \mathrm{N}, \mathrm{O}, \mathrm{O} / \mathrm{C}$, and $(\mathrm{O}+\mathrm{N}) / \mathrm{C}$ decreased with the pyrolyzing temperatures, due to the dehydration, decarboxylation, and decarbonylation in the pyrolysis process [24]. The distinct surface and structure characteristics of biochars, regulated by the biomass feedstock and pyrolytic temperatures, could significantly influence the adsorption of DBSA on biochars.

Table 1. BET- $\mathrm{N}_{2}$ surface area, pore volume, and average pore size of biochars.

\begin{tabular}{cccc}
\hline Samples & Surface Area $\left(\mathbf{m}^{\mathbf{2}} \mathbf{g}\right)$ & Pore Volume $\left(\mathbf{c m}^{\mathbf{3}} / \mathbf{g}\right)$ & Average Pore Size $(\mathbf{n m})$ \\
\hline C300 & 4.52 & 0.0042 & 8.33 \\
C700 & 375.89 & 0.2302 & 3.98 \\
P300 & 1.29 & 0.0023 & 12.27 \\
P700 & 105.88 & 0.0721 & 5.53 \\
\hline
\end{tabular}

Table 2. Elemental composition (on a dry mass basis) and atomic ratios of biochars.

\begin{tabular}{cccccccccc}
\hline Samples & $\mathbf{C ~ ( \% )}$ & $\mathbf{H ~ ( \% )}$ & $\mathbf{N ~ ( \% )}$ & $\mathbf{O}(\mathbf{\%})$ & $\mathbf{H} / \mathbf{C}$ & $\mathbf{O} / \mathbf{C}$ & $\mathbf{C} / \mathbf{N}$ & $\mathbf{( O + N ) / C}$ & Ash (\%) \\
\hline C300 & 61.67 & 5.41 & 1.88 & 31.04 & 1.05 & 0.43 & 38.27 & 0.46 & 0.44 \\
C700 & 83.76 & 1.50 & 1.76 & 10.42 & 0.21 & 0.11 & 55.52 & 0.12 & 2.56 \\
P300 & 59.04 & 5.87 & 5.33 & 27.37 & 1.19 & 0.40 & 12.92 & 0.47 & 2.39 \\
P700 & 69.98 & 2.19 & 3.75 & 18.14 & 0.38 & 0.22 & 21.77 & 0.27 & 5.94 \\
\hline
\end{tabular}

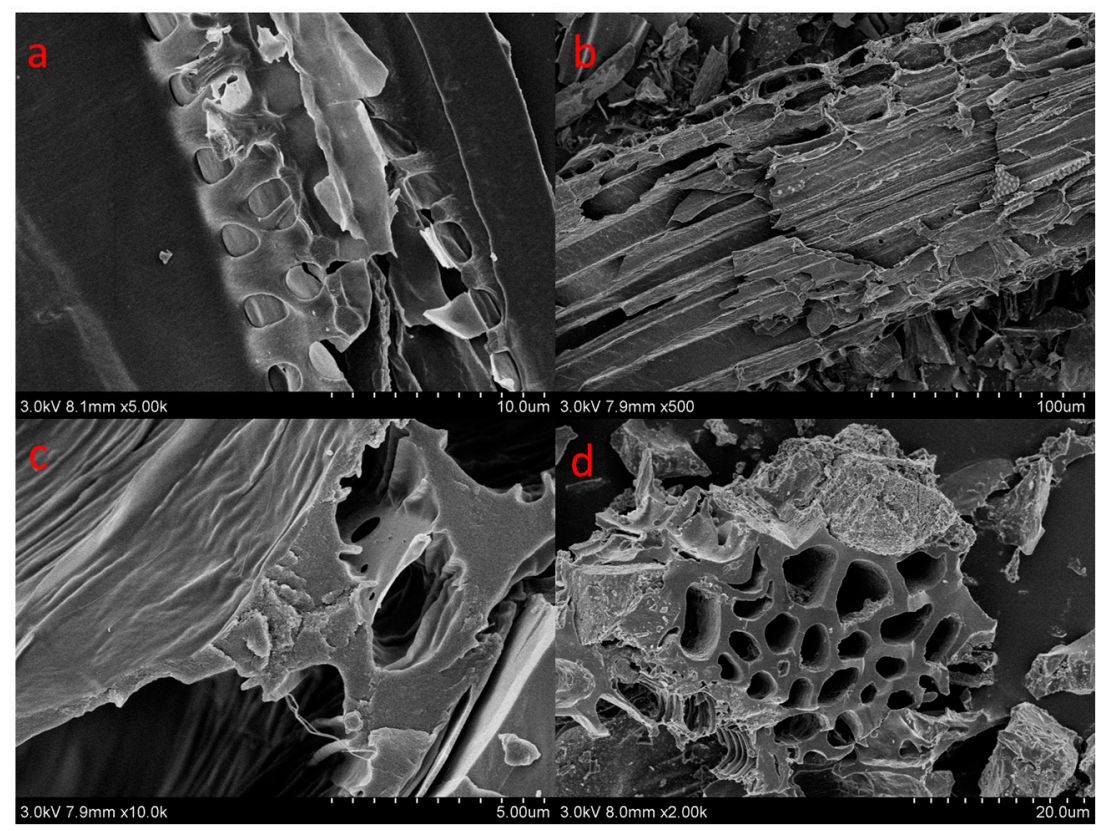

Figure 1. Scanning electron microscope images of C300 (a); C700 (b); P300 (c); and P700 (d). 


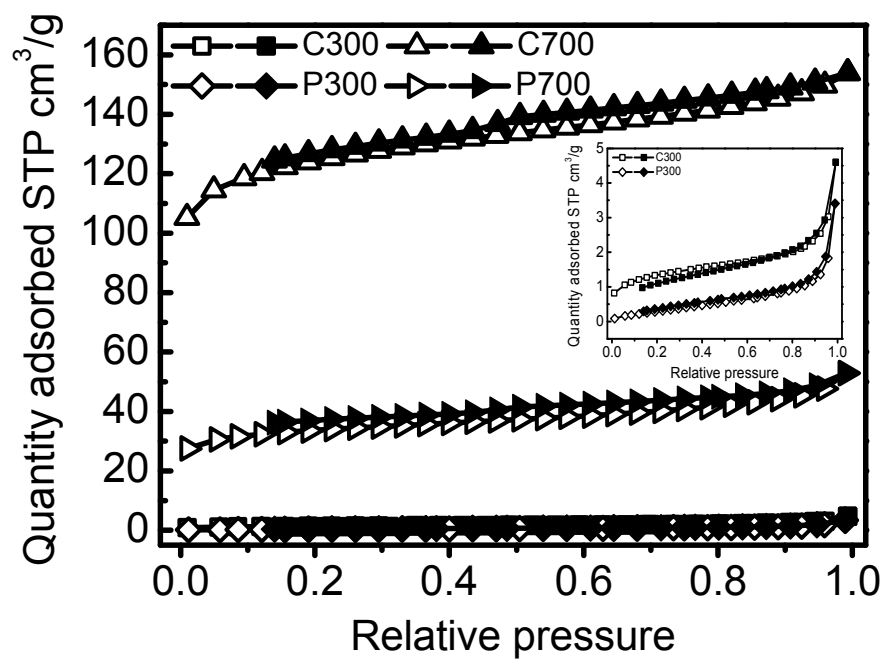

Figure 2. Adsorption and desorption isotherms for biochars. The hollow signs are for the adsorption branch, and the compact signs are for the desorption branch.

\subsection{Adsorption Kinetics and Isotherm}

In Figure 3, results from studying the adsorption kinetics of DBSA on biochars are shown. The results indicated that the adsorption of DBSA on C700, P300, and P700 was relatively slow. However, it was faster than the adsorption of DBSA on soils and Mollisol soil HA [17]. Within $5 \mathrm{~h}$ of solution/biochar contact, $89.67 \%, 78.34 \%$, and $83.09 \%$ of the initial DBSA amount were removed by C700, P300, and P700, respectively. After $10 \mathrm{~h}$, the adsorption of DBSA almost reached its equilibrium with $91.05 \%, 81.69 \%$, and $85.28 \%$ removal efficiencies. For C300, the adsorption seemed to approach equilibrium in $48 \mathrm{~h}$, with a removal efficiency of $89.50 \%$. Kinetic equation parameters for the adsorption of DBSA on biochars are listed in Table 3. Pseudo-second order kinetic was more suitable in describing the adsorption kinetics of DBSA on biochars $\left(\mathrm{R}^{2}, 0.992-0.999\right)$. It was confirmed that chemical adsorption was the rate-limiting mechanism [22]. From the adsorption rate constant, it appears that DBSA adsorbed more quickly to the biochars prepared at high temperature than to the biochars made at low temperature.

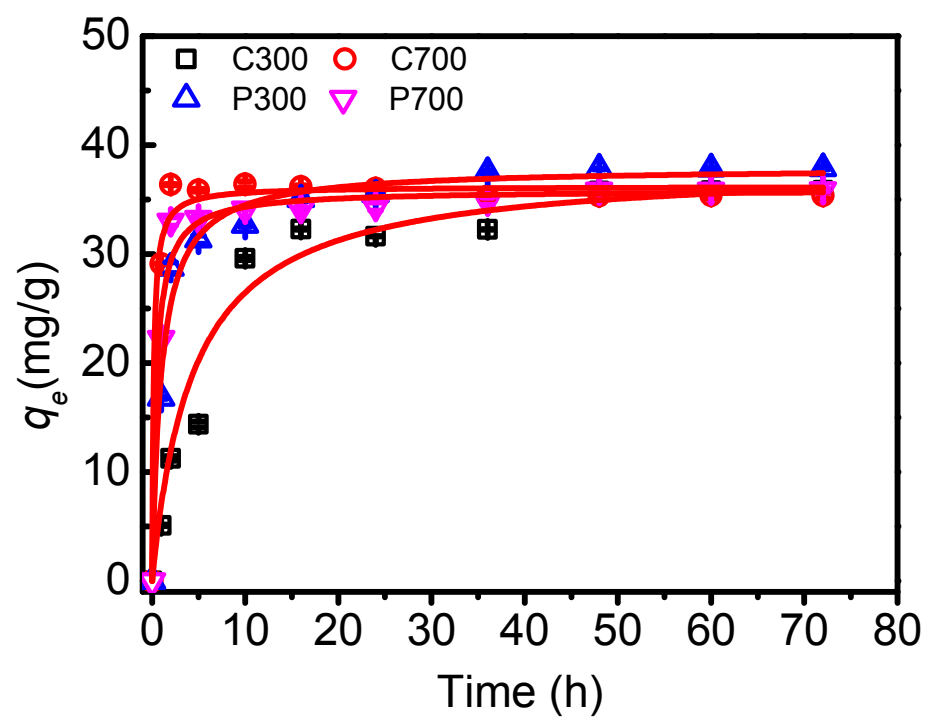

Figure 3. Adsorption dynamics for dodecylbenzene sulfonic acid (DBSA) on crop straw and poplar leaf biochars. The bars are the standard errors. The lines represent pseudo-second order kinetic fitting. 
Table 3. Kinetic equation parameters for the adsorption of DBSA on biochars.

\begin{tabular}{|c|c|c|c|c|c|c|c|}
\hline \multirow[t]{2}{*}{ Sample } & \multicolumn{3}{|c|}{$\begin{array}{c}\text { Pseudo-First Order Kinetic } \\
q_{t}=q_{e}\left[1-\exp \left(-K_{1} t\right)\right]\end{array}$} & \multicolumn{4}{|c|}{$\begin{array}{c}\text { Pseudo-Second Order Kinetic } \\
1 / q_{t}=1 / K_{2} \times q_{e}^{2}+t / q_{e}=1 / v_{0}+t / q_{e}\end{array}$} \\
\hline & $K_{1}\left(\mathrm{~h}^{-1}\right)$ & $q_{e}(\mathrm{mg} / \mathrm{g})$ & $R^{2}$ & $K_{2}(\mathrm{~g} /(\mathrm{mg} \cdot \mathrm{h}))$ & $q_{e}(\mathrm{mg} / \mathrm{g})$ & $v_{0}(\mathrm{mg} /(\mathrm{g} \cdot \mathrm{h}))$ & $R^{2}$ \\
\hline C300 & $0.148 \pm 0.001$ & $34.81=$ & 0.975 & $0.006 \pm 0.000$ & $38.17 \pm 0.053$ & $8.636 \pm 0.054$ & 0.992 \\
\hline C700 & $1.754 \pm 0.012$ & $35.87 \pm 0.060$ & 0.996 & $0.167 \pm 0.004$ & $36.21 \pm 0.070$ & $219.0 \pm 3.931$ & 0.999 \\
\hline P300 & $0.675 \pm 0.016$ & $36.01 \pm 0.048$ & 0.967 & $0.026 \pm 0.001$ & $37.94 \pm 0.074$ & $37.43 \pm 0.900$ & 0.999 \\
\hline P700 & $1.108 \pm 0.021$ & $34.92 \pm 0.095$ & 0.989 & $0.062 \pm 0.002$ & $35.88 \pm 0.126$ & $79.82 \pm 2.537$ & 0.999 \\
\hline
\end{tabular}

$q_{e}$ is the adsorbed amount at equilibrium, $q_{t}$ is the amount of DBSA adsorbed at time $t, K_{1}$ and $K_{2}$ are the pseudo-first order rate constant and pseudo-second order rate constant, $K_{2} q_{e}{ }^{2}\left(v_{0}\right)$ is the initial rate $[25,26]$. Values are mean \pm standard errors.

The adsorption isotherms of DBSA on biochars were demonstrated in Figure 4. DBSA adsorption capacity on biochars increased with the increasing pyrolysis temperature. Linear, Freundlich, and Langmuir models were applied to fit the isotherms, and the parameters of the isotherm equations were listed in Table 4. The linear model fit well for the adsorption of DBSA on C300, which indicated that the DBSA was partitioning into the non-carbonized organic matter of C300 [9]. The adsorption of DBSA on C700, P300, and P700 were best fit to the Langmuir isotherm under the concentration range studied, which confirmed that the adsorption occurred on a homogenous surface by monolayer adsorption [28]. It also indicated that a strong adsorption affinity existed between biochars and DBSA, and it was the anion exchange interaction that made the sulfonate ion adsorbed onto poplar leaf biochars and C700 [29]. Interestingly, the surface area of C700 was the biggest among four samples (Table 1), approximately 3.6 times that of P700 (Table 1), but $q_{\max }$ of DBSA on P700 (155.9 mg/g) was the highest. Furthermore, P300 had the highest average pore size $(12.27 \mathrm{~nm})$, but the lowest $q_{\max }$. Therefore, surface area and average pore size were not the factor governing the adsorption capacity. This suggests that P700 has great potential in pollution control of surfactants.

In Table 5, the $K_{2}$ values were analyzed as a function of some of the characteristics of the biochars (Tables 1, 2, 6 and 7). A strong positive relationship was observed between the values of these adsorption rate constants and surface area, pore volume, and organic free radical concentrations of biochars. At the same time, $K_{2}$ was negatively related to the content of $\mathrm{O}$ and $(\mathrm{O}+\mathrm{N}) / \mathrm{C}$. The statistical analyses reported here have suggested the involvement of these structural parameters in the adsorption process.

Table 4. Parameters for DBSA different adsorption isotherm equations.

\begin{tabular}{|c|c|c|c|c|c|c|c|c|}
\hline \multirow[t]{2}{*}{ Sample } & \multicolumn{2}{|c|}{$\begin{array}{c}\text { Linear } \\
q_{e}=K_{P} C_{e}\end{array}$} & \multicolumn{3}{|c|}{$\begin{array}{c}\text { Langmuir } \\
q_{e}=K q_{\max } C_{e} /\left(1+K C_{e}\right)\end{array}$} & \multicolumn{3}{|c|}{$\begin{array}{l}\text { Freundlich } \\
q_{e}=K_{F} C_{e}\end{array}$} \\
\hline & $\mathrm{K}_{P}(\mathrm{~L} / \mathrm{g})$ & $R^{2}$ & $K(\mathrm{~L} / \mathrm{g})$ & $q_{\max }(\mathrm{mg} / \mathrm{g})$ & $R^{2}$ & $\begin{array}{l}K_{F}(\mathrm{mg} / \mathrm{g} \\
\left.(\mathrm{L} / \mathrm{mg})^{n}\right)\end{array}$ & $\mathbf{n}$ & $R^{2}$ \\
\hline C300 & $0.431 \pm 0.006$ & 0.980 & $7.667 \pm 0.376$ & $74.82 \pm 0.371$ & 0.530 & $2.026 \pm 0.036$ & $0.654 \pm 0.002$ & 0.914 \\
\hline $\mathrm{C} 700$ & $0.769 \pm 0.069$ & 0.588 & $57.50 \pm 19.33$ & $86.22 \pm 0.433$ & 0.981 & $9.427 \pm 0.466$ & $0.468 \pm 0.013$ & 0.948 \\
\hline P300 & $0.442 \pm 0.007$ & 0.347 & $46.33 \pm 4.779$ & $71.33 \pm 1.652$ & 0.983 & $6.448 \pm 0.231$ & $0.489 \pm 0.011$ & 0.745 \\
\hline P700 & $1.199 \pm 0.029$ & 0.592 & $43.50 \pm 4.770$ & $155.9 \pm 23.37$ & 0.981 & $5.047 \pm 0.456$ & $0.675 \pm 0.037$ & 0.954 \\
\hline
\end{tabular}


Table 5. Correlation coefficient of the adsorption rate constants and the structural characteristics of biochars.

\begin{tabular}{|c|c|c|c|c|c|c|c|c|c|c|c|}
\hline Index & $K_{2}$ & Surface Area & $\begin{array}{c}\text { Pore } \\
\text { Volume }\end{array}$ & Average Pore Size & C & $\mathrm{H}$ & $\mathbf{N}$ & $\mathrm{o}$ & $\begin{array}{l}\mathrm{Cl} \\
\mathrm{H}\end{array}$ & $\begin{array}{l}\mathrm{O} / \\
\mathrm{C}\end{array}$ & $\begin{array}{l}\mathrm{Cl} \\
\mathbf{N}\end{array}$ \\
\hline Surface area & $0.99 * *$ & & & & & & & & & & \\
\hline Pore volume & $0.99 * *$ & 1.00 ** & & & & & & & & & \\
\hline Average pore size & -0.75 & -0.80 & -0.81 & & & & & & & & \\
\hline C & $0.97^{*}$ & $0.99^{*}$ & $0.99 *$ & -0.89 & & & & & & & \\
\hline $\mathrm{H}$ & -0.85 & -0.85 & -0.87 & 0.93 & -0.92 & & & & & & \\
\hline $\mathrm{N}$ & -0.42 & -0.53 & -0.53 & 0.70 & -0.57 & 0.42 & & & & & \\
\hline $\mathrm{O}$ & $-0.96^{*}$ & -0.93 & -0.94 & 0.80 & -0.95 * & 0.95 & 0.30 & & & & \\
\hline $\mathrm{C} / \mathrm{H}$ & -0.85 & -0.86 & -0.87 & 0.94 & -0.93 & $1.00^{* *}$ & 0.45 & 0.94 & & & \\
\hline $\mathrm{O} / \mathrm{C}$ & -0.94 & -0.93 & -0.94 & 0.85 & $-0.96^{*}$ & $0.97 *$ & 0.35 & $1.00^{* *}$ & $0.97 *$ & & \\
\hline $\mathrm{C} / \mathrm{N}$ & 0.69 & 0.78 & 0.77 & -0.72 & 0.77 & -0.54 & -0.92 & -0.53 & -0.56 & -0.55 & \\
\hline$(\mathrm{N}+\mathrm{O}) / \mathrm{C}$ & $-0.95 *$ & $-0.96 *$ & $-0.96 *$ & 0.89 & $-0.99 *$ & $0.97 *$ & 0.46 & $0.98^{*}$ & $0.97 *$ & $0.99 * *$ & -0.65 \\
\hline Ash & 0.25 & 0.18 & 0.21 & -0.37 & 0.28 & -0.60 & 0.37 & -0.52 & -0.58 & -0.53 & -0.35 \\
\hline Aliphatic & -0.81 & -0.84 & -0.85 & $0.99 * *$ & -0.92 & $0.96^{*}$ & 0.65 & 0.86 & $0.97 *$ & 0.90 & -0.70 \\
\hline Heteroaliphatic & -0.89 & -0.83 & -0.84 & 0.64 & -0.84 & 0.87 & 0.03 & $0.96^{*}$ & 0.86 & 0.94 & -0.30 \\
\hline Acetal & -0.95 & -0.90 & -0.90 & 0.59 & -0.87 & 0.80 & 0.11 & 0.95 & 0.79 & 0.92 & -0.43 \\
\hline Aromatic & 0.92 & 0.92 & 0.93 & -0.91 & $0.96 *$ & $-0.99 * *$ & -0.43 & $-0.98 *$ & $-0.99 *$ & $-0.99 * *$ & 0.60 \\
\hline Carboxyl & 0.23 & 0.13 & 0.15 & -0.15 & 0.18 & -0.46 & 0.59 & -0.47 & -0.43 & -0.46 & -0.49 \\
\hline Carbonyl & 0.50 & 0.59 & 0.60 & -0.88 & $0.68^{*}$ & -0.65 & -0.94 & -0.47 & -0.68 & -0.54 & 0.84 \\
\hline Aliphaticity & -0.92 & -0.91 & -0.93 & 0.91 & $-0.96 *$ & $0.99^{*}$ & 0.42 & 0.98 & $0.99^{*}$ & $0.99 * *$ & -0.59 \\
\hline Hydrophobic functional group & 0.90 & 0.84 & 0.85 & -0.61 & 0.83 & -0.84 & -0.02 & $-0.96 *$ & -0.83 & -0.93 & 0.31 \\
\hline Hydrophilic functional group & -0.90 & -0.84 & -0.85 & 0.61 & -0.83 & 0.84 & 0.02 & $0.96^{*}$ & 0.83 & 0.93 & -0.31 \\
\hline Organic free radical concentration & $0.97^{*}$ & $0.98^{*}$ & $0.98^{*}$ & -0.71 & 0.94 & -0.74 & -0.56 & -0.86 & -0.75 & -0.84 & 0.82 \\
\hline
\end{tabular}


Table 5. Cont

\begin{tabular}{|c|c|c|c|c|c|c|c|c|c|c|c|}
\hline Index & $\begin{array}{c}(\mathrm{N}+\mathrm{O}) / \\
\mathrm{C}\end{array}$ & Ash & Aliphatic & $\begin{array}{c}\text { Hetero } \\
\text { Aliphatic }\end{array}$ & Acetal \% & Aromatic & Carboxyl & Carbonyl & Aliphaticity & $\begin{array}{l}\text { Hydrophobic } \\
\text { Functional } \\
\text { Group }\end{array}$ & $\begin{array}{c}\text { Hydrophilic } \\
\text { Functional } \\
\text { Group }\end{array}$ \\
\hline \multicolumn{12}{|l|}{ Surface area } \\
\hline \multicolumn{12}{|l|}{ Pore volume } \\
\hline \multirow{2}{*}{\multicolumn{12}{|c|}{ Average pore size }} \\
\hline & & & & & & & & & & & \\
\hline \multicolumn{12}{|l|}{$\begin{array}{l}\mathrm{C} \\
\mathrm{H}\end{array}$} \\
\hline \multicolumn{12}{|l|}{$\mathrm{N}$} \\
\hline \multicolumn{12}{|l|}{$\mathrm{O}$} \\
\hline \multirow{2}{*}{\multicolumn{12}{|c|}{$\begin{array}{l}\mathrm{O} / \mathrm{C} \\
\mathrm{C} / \mathrm{N}\end{array}$}} \\
\hline & & & & & & & & & & & \\
\hline$(\mathrm{N}+\mathrm{O}) / \mathrm{C}$ & & & & & & & & & & & \\
\hline Ash & -0.44 & & & & & & & & & & \\
\hline Aliphatic & 0.93 & -0.42 & & & & & & & & & \\
\hline Heteroaliphatic & 0.90 & -0.64 & 0.72 & & & & & & & & \\
\hline Acetal & 0.89 & 0.42 & 0.67 & $0.97 *$ & & & & & & & \\
\hline Aromatic & $-1.00 * *$ & 0.52 & -0.95 & -0.90 & -0.87 & & & & & & \\
\hline Carboxyl & -0.34 & $0.95 *$ & -0.22 & -0.65 & -0.47 & 0.41 & & & & & \\
\hline Carbonyl & -0.63 & -0.02 & 0.83 & -0.23 & -0.22 & 0.62 & -0.29 & & & & \\
\hline Aliphaticity & $0.99 * *$ & -0.53 & 0.95 & 0.91 & 0.86 & $-1.00 * *$ & -0.42 & -0.62 & & & \\
\hline Hydrophobic functional group & -0.89 & 0.59 & -0.69 & $-1.00 * *$ & $-0.98 *$ & 0.89 & 0.63 & 0.20 & -0.89 & & \\
\hline Hydrophilic functional group & 0.89 & -0.59 & 0.69 & $1.00^{* *}$ & $0.98 *$ & -0.89 & -0.63 & -0.20 & 0.89 & $-1.00 * *$ & \\
\hline Organic free radical concentration & -0.88 & 0.00 & -0.75 & -0.75 & -0.86 & 0.83 & -0.02 & 0.55 & -0.82 & 0.77 & -0.77 \\
\hline
\end{tabular}

Table 6. Intensity distribution in the ${ }^{13} \mathrm{C}$ nuclear magnetic resonance (NMR) spectra of biochars.

\begin{tabular}{|c|c|c|c|c|c|c|c|c|c|}
\hline Samples & Aliphatic \% & $\begin{array}{c}\text { Heteroaliphatic } \\
\%\end{array}$ & Acetal \% & Aromatic \% & Carboxyl \% & Carbonyl \% & Aliphaticity \% & $\begin{array}{c}\text { Hydrophobic } \\
\text { Functional } \\
\text { Group \% }\end{array}$ & $\begin{array}{c}\text { Hydrophilic } \\
\text { Functional } \\
\text { Group \% }\end{array}$ \\
\hline & $80-60$ & $860-90$ & $890-110$ & $\delta 110-165$ & $\delta 165-190$ & $\delta 190-230$ & & & \\
\hline C300 & 22.91 & 23.98 & 10.18 & 35.98 & 4.81 & 2.13 & 61.33 & 69.07 & 30.93 \\
\hline C300-DBSA & 23.75 & 17.24 & 8.78 & 42.22 & 5.61 & 2.39 & 54.10 & 74.75 & 25.25 \\
\hline C700 & 0.10 & 1.52 & 4.28 & 85.83 & 5.93 & 2.35 & 6.45 & 90.21 & 9.79 \\
\hline C700-DBSA & 4.29 & 1.12 & 3.22 & 82.07 & 5.74 & 3.55 & 9.51 & 89.58 & 10.42 \\
\hline P300 & 36.66 & 14.41 & 7.74 & 34.25 & 6.30 & 0.64 & 63.20 & 78.65 & 21.35 \\
\hline P300-DBSA & 35.19 & 12.80 & 7.32 & 36.40 & 7.14 & 1.14 & 60.31 & 78.91 & 21.09 \\
\hline P700 & 7.87 & 6.96 & 7.07 & 69.03 & 7.17 & 1.90 & 24.08 & 83.97 & 16.03 \\
\hline P700-DBSA & 6.29 & 6.40 & 7.75 & 68.80 & 7.37 & 3.38 & 22.90 & 82.84 & 17.16 \\
\hline
\end{tabular}




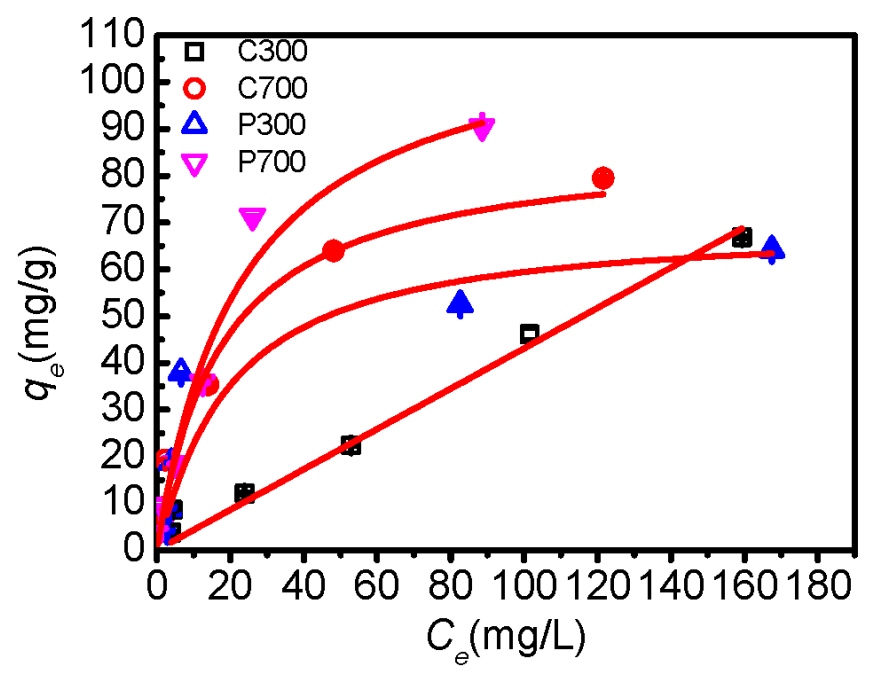

Figure 4. Adsorption isotherms for DBSA on crop straw and poplar leaf biochars. The bars are the standard errors. The lines represent linear and Langmuir equations fitting.

Table 7. Electron spin resonance (ESR) parameters for biochars and its products of interaction with DBSA.

\begin{tabular}{ccc}
\hline Samples & $\begin{array}{c}\text { Organic Free Radical } \\
\text { Concentration }\left(\text { Spins/g } \times \mathbf{1 0}^{\mathbf{1 4}} \text { ) }\right.\end{array}$ & Line Width (Gauss) \\
\hline C300 & 0.244 & 4.7 \\
C300-DBSA & 0.297 & 4.7 \\
C700 & 11.89 & 5.3 \\
C700-DBSA & 9.632 & 4.4 \\
P300 & 0.132 & 5.6 \\
P300-DBSA & 0.196 & 5.3 \\
P700 & 1.266 & 3.2 \\
P700-DBSA & 2.599 & 4.7 \\
\hline
\end{tabular}

Note: The spectroscopic splitting factor is 2.004 .

\subsection{Adsorption Mechanisms}

As can be seen from the Fourier transform infrared (FTIR) spectra in Figures 5 and 6, the broad band at $3365 \mathrm{~cm}^{-1}$ was ascribed to the $\mathrm{O}-\mathrm{H}$ stretching vibration of hydroxyl functional groups [30]. The peaks at $2927 \mathrm{~cm}^{-1}$ and $2856 \mathrm{~cm}^{-1}$ were attributed to symmetric C-H stretching of alkyl groups [31]. P300 contained more alkyl groups than the other biochars, due to the stronger adsorption at $2927 \mathrm{~cm}^{-1}$. The bands at $1707 \mathrm{~cm}^{-1}$ and $1612 \mathrm{~cm}^{-1}$ were assigned to $C=O$ vibrations [32]. The band at $1212 \mathrm{~cm}^{-1}$ was indicative of $\mathrm{C}-\mathrm{O}$ stretching vibration in phenol and alcohol [33]. The peaks in $831-884 \mathrm{~cm}^{-1}$ corresponded to an aromatic C-H stretching vibration [34]. As can be seen from the FTIR results of C300, C700, P300, and P700, higher pyrolysis temperature caused the decrease of the aliphatic $\mathrm{C}-\mathrm{H}$ groups, and the disappearance of the peaks at $1707 \mathrm{~cm}^{-1}$. These results were consistent with the elemental analysis results of lower ratios of $\mathrm{H} / \mathrm{C}$ and $\mathrm{O} / \mathrm{C}$. The obvious changes of the structural characters might be the reason for the different adsorption sites and adsorption mechanism. The FTIR spectra of biochars after the adsorption of DBSA are also presented in Figures 5 and 6. In Figure 5, the adsorption intensities at $1707 \mathrm{~cm}^{-1}$ and $1212 \mathrm{~cm}^{-1}$ in the FTIR spectrum of C300-DBSA became higher than that of the pristine $\mathrm{C} 300$ after the adsorption, which indicated that the adsorption took place in $\mathrm{C}=\mathrm{O}$ and $\mathrm{C}-\mathrm{O}$ groups, and $\mathrm{H}$ bond formed. $\mathrm{H}$ bond may be formed between the $\mathrm{H}$ atom in hydroxyl functional groups of phenol or carboxyl, and the $\mathrm{O}$ atom of DBSA. The presence of aromatic $\mathrm{C}-\mathrm{H}$ groups at $884 \mathrm{~cm}^{-1}$ in the C700-DBSA sample confirmed that the aromatic C-H groups of DBSA were adsorbed on $\mathrm{C} 700$. 


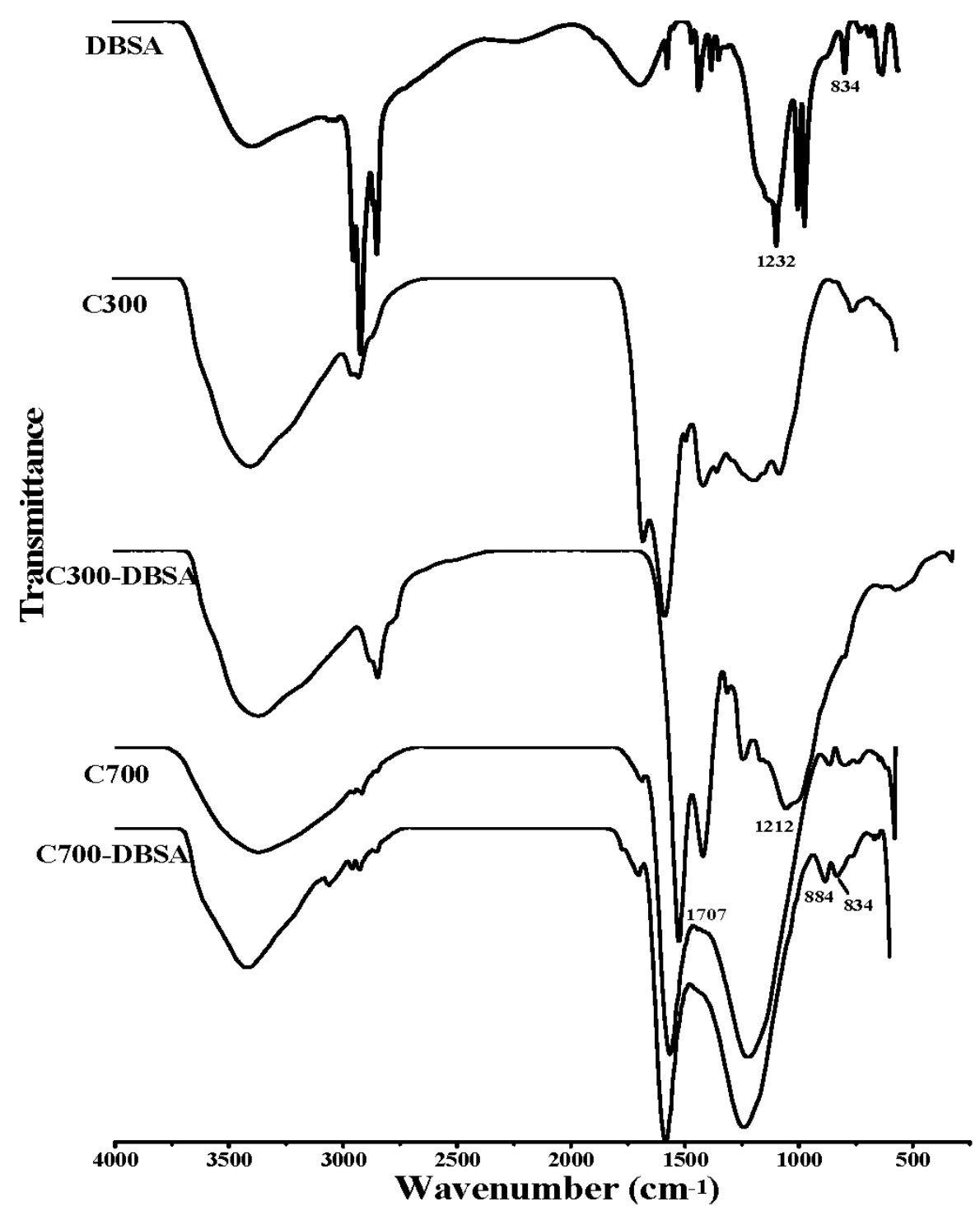

Figure 5. Infrared (IR) spectra of DBSA, crop straw biochars and their interaction complexes.

In Figure 6, after the adsorption of DBSA on P300, the band at $3365 \mathrm{~cm}^{-1}$ shifted to the lower frequency $3333 \mathrm{~cm}^{-1}$, which suggested the strong interaction formed through the $\mathrm{H}$ bond [35]. An increase in the intensity of the band at $1225 \mathrm{~cm}^{-1}$ could also confirm the formation of a $\mathrm{H}$ bond [33]. The peaks at $2926 \mathrm{~cm}^{-1}$ and $2854 \mathrm{~cm}^{-1}$ became stronger, which indicated that the aliphatic $\mathrm{C}-\mathrm{H}$ groups of DBSA were adsorbed on P300 [2]. The shape of the adsorbing peak of $1612 \mathrm{~cm}^{-1}$ became wider and the peak intensity increased, which could be ascribed to the adsorption on $\mathrm{C}=\mathrm{O}$ groups. The appearance of an additional band at $831 \mathrm{~cm}^{-1}$ was the consequence of the interaction of aromatic $\mathrm{C}-\mathrm{H}$ groups of DBSA with P300. The FTIR spectra of P700-DBSA showed no significant change in comparison to P700, which indicated that the adsorption of DBSA on P700 did not alter the structure.

Figures 7 and 8 are the ${ }^{13} \mathrm{C}-\mathrm{NMR}$ spectra of biochars and biochars-DBSA complexes, respectively. The structural carbon distribution of the biochars and their complexes was calculated according to the ${ }^{13} \mathrm{C}-\mathrm{NMR}$ spectra, and is shown in Table 6. With the increase of the temperature, the contents of aliphatic carbon, heteroaliphatic carbon, and acetal carbon all decreased. At the same time, the contents of aromatic carbon, carboxyl carbon, and carbonyl carbon increased. Poplar leaf biochars had higher contents of aliphatic carbon and carboxyl carbon than corn straw biochars. 


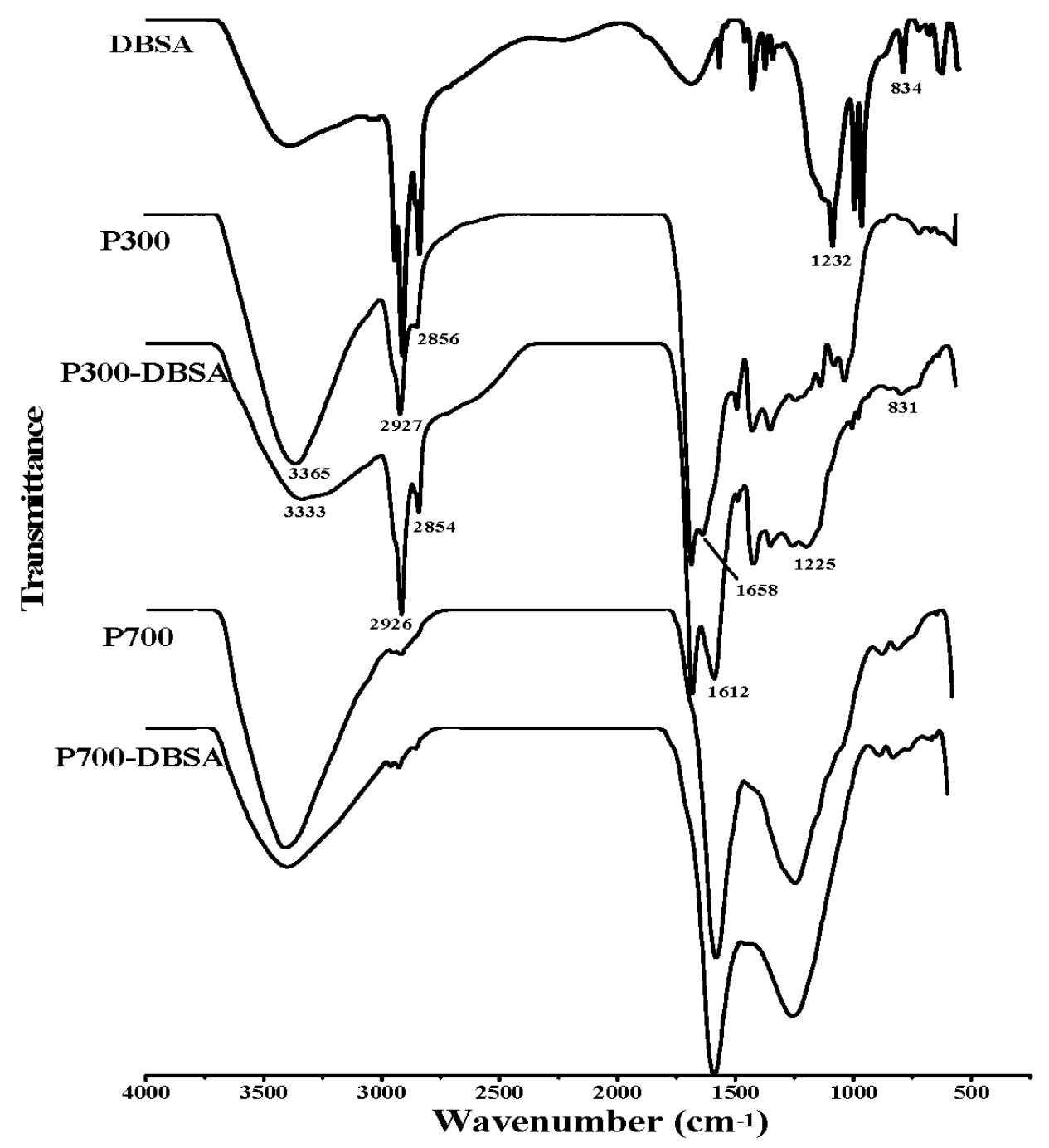

Figure 6. IR spectra of DBSA, poplar leaf biochars, and their interaction complexes.

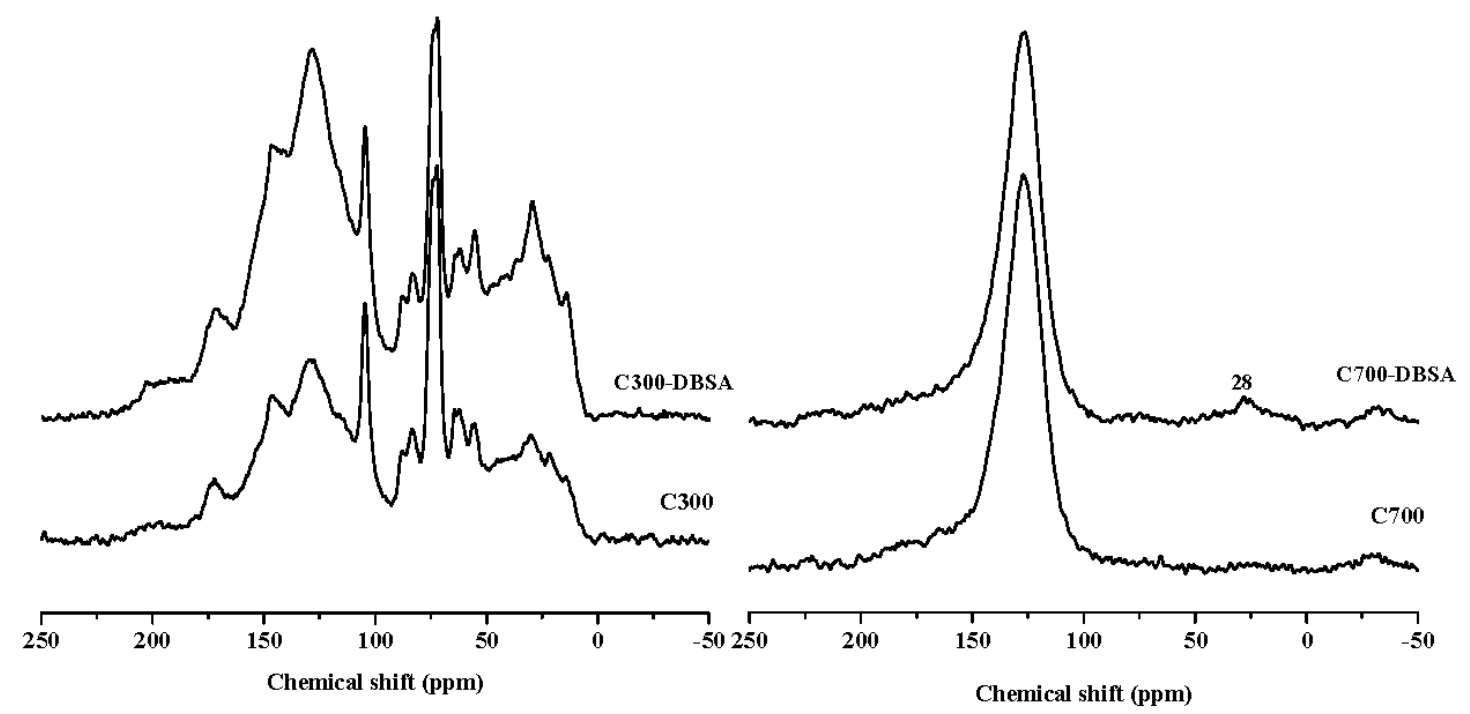

Figure 7. ${ }^{13} \mathrm{C}-\mathrm{NMR}$ spectra of crop straw biochars, and their interaction complexes. 


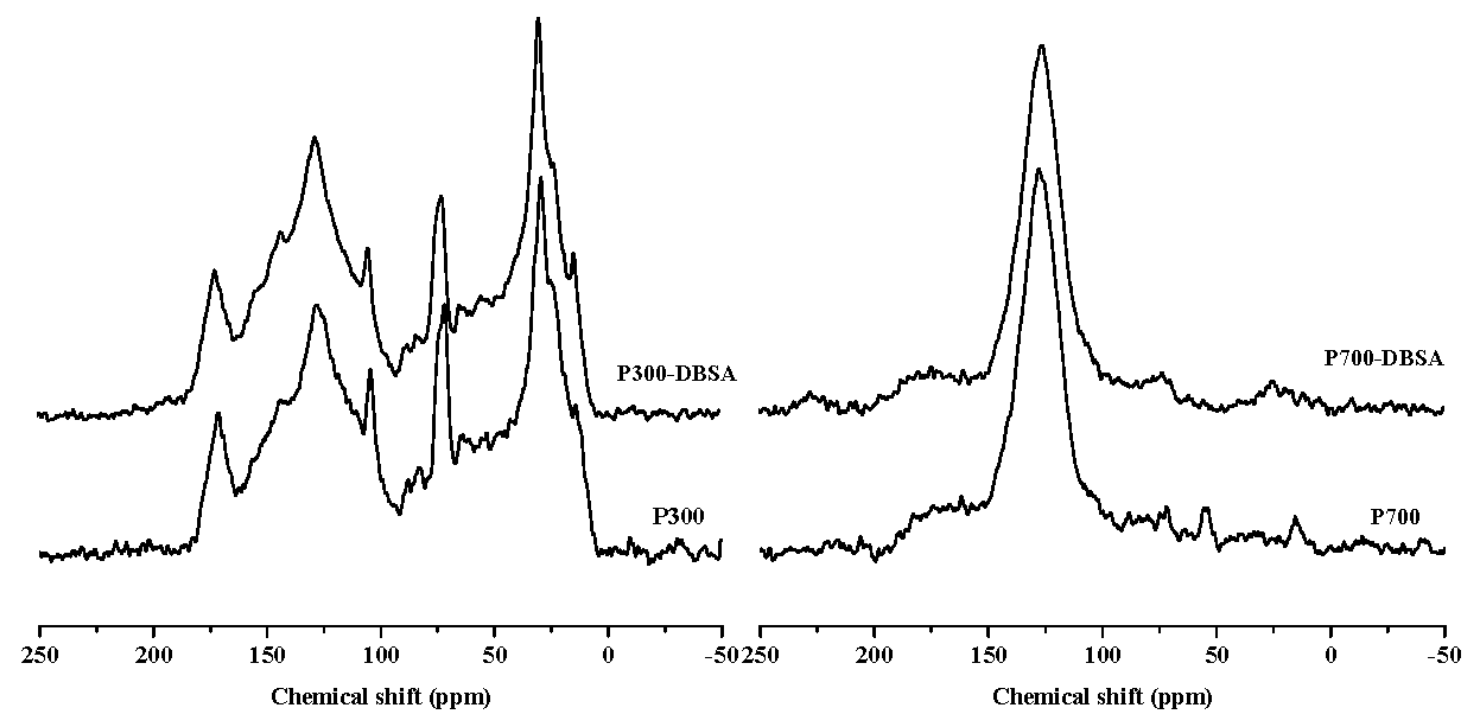

Figure $8 .{ }^{13} \mathrm{C}-\mathrm{NMR}$ spectra of poplar leaf biochars and their interaction complexes.

For C300, the content of aromatic carbon changed the most, from $35.98 \%$ before the adsorption to $42.22 \%$ after the adsorption. The change rate was the biggest $(17.34 \%)$, which suggested that adsorption took place on aromatic carbon. The change rate of the aliphatic carbon of $C 700$ was up to $4190 \%$, and the presence of the long chain polymethylene carbon $(28 \mathrm{ppm})$ implied that adsorption happened on long chain polymethylene carbon [36]. The adsorption mainly happened on carbonyl carbons of poplar leaf biochars due to the biggest change ratios of $78.13 \%$ and $77.89 \%$ for $\mathrm{P} 300$ and P700, respectively. After the adsorption of DBSA, the hydrophobicity of C700, Y300, and Y700 hardly changed.

Organic free radicals in humic acid or biochars have attracted considerable attention because of their potential for the adsorption and degradation of organic contaminants [37,38]. The $g$ values observed for the biochars-DBSA complexes were the same as the $g$ values of original biochars, thus indicating that no additional free radical species were generated [39]. Organic free radical concentrations increased in the interaction products of biochars and DBSA, relative to the original biochars, in the order: P700 > P300 > C300. These results could be the reason for the formation of charge-transfer between the electron donating carbonyl groups of biochars and the electron acceptor benzene ring of DBSA [40]. The enlargement of the line width in the interaction product of P700-DBSA was the consequence of the formation of covalent bonds between DBSA and P700 [39]. The covalent bonds might play a more important role in making the adsorption capacity of P700 higher than that of other biochars.

\section{Conclusions}

In this study, biochars from crop straw and poplar leaf have been prepared at $300{ }^{\circ} \mathrm{C}$ and $700{ }^{\circ} \mathrm{C}$, respectively. The differences within the pyrolysis temperatures resulted in noticeable changes in the surface morphologies and structural characteristics of biochars derived from different biomass feedstocks. The adsorption kinetics of crop straw and poplar leaf biochars obeyed the pseudo-second order rate model. The study also investigated the adsorption abilities and adsorption mechanisms of DBSA on two different biochars. Isotherm analysis showed that the linear model fit well with the experiment data of C300, and the Langmuir model fit well with the data of C700, P300, and P700. The adsorption mechanisms of DBSA on crop straw biochars included partition, $\mathrm{H}$ bonds, and charge-transfer bonds. The adsorption sites were $\mathrm{C}=\mathrm{O}, \mathrm{C}-\mathrm{O}$, aromatic $\mathrm{C}$, aromatic $\mathrm{C}-\mathrm{H}$ groups, and long chain polymethylene carbon. IR spectra and ESR spectra also confirmed that $\mathrm{H}$ bonds, charge-transfer, and covalent bonds were the main adsorption mechanisms between DBSA and poplar leaf biochars. The adsorption mainly took place on the aliphatic $\mathrm{C}-\mathrm{H}, \mathrm{C}=\mathrm{O}, \mathrm{C}-\mathrm{O}$ and aromatic $\mathrm{C}-\mathrm{H}$ groups. 
Acknowledgments: This research was supported by the National Natural Science Foundation of China (41571317, 41271331) and China Postdoctoral Science Foundation (2016M591267).

Author Contributions: Nan Zhao and Yizhong Lv designed this research; Nan Zhao and Ling Zhu conducted this adsorption experiment; Nan Zhao, Xixiang Yang and Jing Zhang wrote and edited this paper.

Conflicts of Interest: The authors declare no conflict of interest.

\section{References}

1. Westall, J.C.; Chen, H.; Zhang, W.J.; Brownawell, B.J. Sorption of linear alkylbenzenesulfonates on sediment materials. Environ. Sci. Technol. 1999, 33, 3110-3118. [CrossRef]

2. Tan, X.L.; Fang, M.; Chen, C.L.; Yu, S.M.; Wang, X.K. Counterion effects of nickel and sodium dodecylbenzene sulfonate adsorption to multiwalled carbon nanotubes in aqueous solution. Carbon 2008, 46, 1741-1750. [CrossRef]

3. Fernández-Ramos, C.; Ballesteros, O.; Zafra-Gómez, A.; Blanc-García, R.; Navalón, A.; Crovetto, S.I.; Oliver-Rodríguez, B.; García-Delgado, R.A.; Vílchez, J.L. Sorption and desorption of alcohol sulfate surfactants in an agricultural soil. Environ. Toxicol. Chem. 2014, 33, 508-515. [CrossRef] [PubMed]

4. Thangalazhy-Gopakumar, S.; Adhikari, S.; Ravindran, H.; Gupta, R.B.; Fasina, O.; Tu, M.; Fernando, S.D. Physiochemical properties of bio-oil produced at various temperatures from pine wood using an auger reactor. Bioresour. Technol. 2010, 101, 8389-8395. [CrossRef] [PubMed]

5. Dong, X.L.; Ma, L.Q.; Li, Y.C. Characteristics and mechanisms of hexavalent chromium removal by biochar from sugar beet tailing. J. Hazard. Mater. 2011, 190, 909-915. [CrossRef] [PubMed]

6. Novak, J.M.; Busscher, W.J.; Laird, D.L.; Ahmedna, M.; Watts, D.W.; Niandou, M.A.S. Impact of biochar amendment on fertility of a southeastern coastal plain soil. Soil Sci. 2009, 174, 105-112. [CrossRef]

7. Peterson, S.C.; Jackson, M.A. Simplifying pyrolysis: Using gasification to produce corn stover and wheat straw biochar for sorptive and horticultural media. Ind. Crops Prod. 2014, 53, 228-235. [CrossRef]

8. Srinivasan, P.; Sarmah, A.K. Characterisation of agricultural waste-derived biochars and their sorption potential for sulfamethoxazole in pasture soil: A spectroscopic investigation. Sci. Total Environ. 2015, 502, 471-480. [CrossRef] [PubMed]

9. Chen, B.L.; Chen, Z.M. Sorption of naphthalene and 1-naphthol by biochars of orange peels with different pyrolytic temperatures. Chemosphere 2009, 76, 127-133. [CrossRef] [PubMed]

10. Zhang, J.; Liu, J.; Liu, R.L. Effects of pyrolysis temperature and heating time on biochar obtained from the pyrolysis of straw and lignosulfonate. Bioresour. Technol. 2015, 176, 288-291. [CrossRef] [PubMed]

11. Zhang, P.; Sun, H.W.; Li, Y.; Sun, T.H. Adsorption and catalytic hydrolysis of carbaryl and atrazine on pig manure-derived biochars: Impact of structural properties of biochars. J. Hazard. Mater. 2013, 244-245, 217-224. [CrossRef] [PubMed]

12. Yao, H.; Lu, J.; Wu, J.; Lu, Z.Y.; Wilson, P.C.; Shen, Y. Adsorption of fluoroquinolone antibiotics by wastewater sludge biochar: Role of the sludge source. Water Air Soil Pollut. 2013, 224, 1370. [CrossRef]

13. Rodríguez-Cruz, M.S.; Sanchez-Martin, M.J.; Sanchez-Camazano, M. A comparative study of adsorption of an anionic and a non-ionic surfactant by soils based on physicochemical and mineralogical properties of soils. Chemosphere 2005, 61, 56-64. [CrossRef] [PubMed]

14. Rodríguez-Sarmiento, D.C.; Pinzón-Bello, J.A. Adsorption of sodium dodecylbenzene sulfonate on organophilic bentonites. Appl. Clay Sci. 2001, 18, 173-181. [CrossRef]

15. Cotoruelo, L.M.; Marqués, M.D.; Rodríguez-Mirasol, J.; Rodríguez, J.J.; Cordero, T. Lignin-based activated carbons for adsorption of sodium dodecylbenzene sulfonate: Equilibrium and kinetic studies. J. Colloid Interface Sci. 2009, 332, 39-45. [CrossRef] [PubMed]

16. Sastry, N.Y.; Séquaris, J.M.; Schwuger, M.J. Adsorption of polyacrylic acid and sodium dodecylbenzenesulfonate on kaolinite. J. Colloid Interface Sci. 1995, 3171, 224-233. [CrossRef]

17. Zhao, N.; Lv, Y.Z.; Song, G.X.; Zhang, J. Sorption behavior of dodecylbenzene sulfonic acid on humic acids from Mollisol and Alluvial soils. Environ. Earth Sci. 2016, 75, 1-8. [CrossRef] 
18. Ando, N.; Kuwabara, Y.; Kodama, T.; Mori, Y.H. Surface tensions of aqueous solutions of lithium dodecyl sulfate, sodium oleate, and dodecylbenzene sulfonic acid in contact with methane under hydrate-forming conditions. Fluid Phase Equilib. 2012, 314, 146-151. [CrossRef]

19. Jiang, J.H.; Zhang, L.; Wang, X.Y.; Holm, N.; Rajagopalan, K.; Chen, F.L.; Ma, S.G. Highly ordered macroporous woody biochar with ultra-high carbon content as supercapacitor electrodes. Electrochim. Acta 2013, 113, 481-489. [CrossRef]

20. Zhao, N.; Lv, Y.Z.; Yang, X.X. A new 3D conceptual structures modeling of biochars by molecular mechanics and molecular dynamic simulation. J. Soil Sediments 2017, 17, 641-655. [CrossRef]

21. Keiluweit, M.; Nico, P.S.; Johnson, M.G.; Kleber, M. Dynamic molecular structure of plant biomass-derived black carbon (biochar). Environ. Sci. Technol. 2010, 44, 1247-1253. [CrossRef] [PubMed]

22. Chen, X.C.; Chen, G.C.; Chen, L.G.; Chen, Y.X.; Lehmann, J.; McBride, M.B.; Hay, A.G. Adsorption of copper and zinc by biochars produced from pyrolysis of hardwood and corn straw in aqueous solution. Bioresour. Technol. 2011, 102, 8877-8884. [CrossRef] [PubMed]

23. Chen, B.L.; Johnson, E.J.; Chefetz, B. Sorption of polar and nonpolar aromatic organic contaminants by plant cuticular materials: The role of polarity and accessibility. Environ. Sci. Technol. 2005, 39, 6138-6146. [CrossRef] [PubMed]

24. Li, J.; Liang, N.; Jin, X.; Zhou, D.; Li, H.; Wu, M.; Pan, B. The role of ash content on bisphenol a sorption to biochars derived from different agricultural wastes. Chemosphere 2017, 171, 66-73. [CrossRef] [PubMed]

25. Rapti, S.; Pournara, A.; Sarma, D.; Papadas, I.T.; Armatas, G.S.; Tsipis, A.C.; Lazarides, T.; Kanatzidis, M.G.; Manos, M.J. Selective capture of hexavalent chromium from an anion-exchange column of metal organic resin-alginic acid composite. Chem. Sci. 2016, 7, 2427-2436. [CrossRef]

26. Wang, M.S.; Liao, L.B.; Zhang, X.L.; Li, Z.H. Adsorption of low concentration humic acid from water by palygorskite. Appl. Clay Sci. 2012, 67-68, 164-168. [CrossRef]

27. Inyang, M.; Gao, B.; Zimmerman, A.; Zhou, Y.M.; Cao, X.D. Sorption and cosorption of lead and sulfapyridine on carbon nanotube-modified biochars. Environ. Sci. Pollut. Res. 2015, 22, 1868-1876. [CrossRef] [PubMed]

28. Arampatzidou, A.C.; Deliyanni, E.A. Comparison of activation media and pyrolysis temperature for activated carbons development by pyrolysis of potato peels for effective adsorption of endocrine disruptor bisphenol-A. J. Colloid Interface Sci. 2016, 466, 101-112. [CrossRef] [PubMed]

29. Chao, H.P.; Lee, C.K.; Juang, L.C.; Han, Y.L. Sorption of organic compounds, oxyanions, and heavy metal ions on surfactant modified titanate nanotubes. Ind. Eng. Chem. Res. 2013, 52, 9843-9850. [CrossRef]

30. Yan, Q.G.; Wan, C.X.; Liu, J.; Gao, J.S.; Yu, F.; Zhang, J.L.; Cai, Z.Y. Iron nanoparticles in situ encapsulated in biochar-based carbon as an effective catalyst for the conversion of biomass-derived syngas to liquid hydrocarbons. Green Chem. 2013, 15, 1631-1640. [CrossRef]

31. Kapoor, A.; Viraraghavan, T. Heavy metal biosorption sites in Aspergillus niger. Bioresour. Technol. 1997, 61, 221-227. [CrossRef]

32. D'Orazio, V.; Loffredo, E.; Brunetti, G.; Senesi, N. Triallate adsorption onto humic acids of different origin and nature. Chemosphere 1999, 39, 183-198. [CrossRef]

33. Russell, L.; Stokes, A.R.; Macdonald, H.; Muscolo, A.; Nardi, S. Stomatal responses to humic substances and auxin are sensitive to inhibitors of phospholipase $A_{2}$. Plant Soil 2006, 283, 175-185. [CrossRef]

34. Hossain, M.K.; Strezov, V.; Chan, K.Y.; Ziolkowski, A.; Nelson, P.F. Influence of pyrolysis temperature on production and nutrient properties of wastewater sludge biochar. J. Environ. Manag. 2011, 92, 223-228. [CrossRef] [PubMed]

35. Baes, A.U.; Bloom, P.R. Diffuse reflectance and transmission Fourier Transform Infrare (DRIFT) spectroscopy of humic and fulvic acids. Soil Sci. Soc. Am. J. 1989, 53, 695-700. [CrossRef]

36. Zhang, J.J.; Hu, F.; Li, H.X.; Gao, Q.; Song, X.Y.; Ke, X.K.; Wang, L.C. Effects of earthworm activity on humus composition and humic acid characteristics of soil in a maize residue amended rice-wheat rotation agroecosystem. Appl. Soil Ecol. 2001, 51, 1-8. [CrossRef]

37. Senesi, N. Binding mechanisms of pesticides to soil humic substances. Sci. Total Environ. 1992, 123-124, 63-76. [CrossRef]

38. Fang, G.; Zhu, C.; Dionysiou, D.D.; Gao, J.; Zhou, D. Mechanism of hydroxyl radical generation from biochar suspensions: Implications to diethyl phthalate degradation. Bioresour. Technol. 2015, 176, 210-217. [CrossRef] [PubMed] 
39. Senesi, N.; Testini, C. Physico-chemical investigations of interaction mechanisms between s-triazineherbicides and soil humic acids. Geoderma 1982, 28, 129-146. [CrossRef]

40. Mattson, J.S.; Mark, H.B.; Malbin, M.D.; Weber, W.J.; Critten, J.C. Surface chemistry of active carbon: Specific adsorption of phenol. J. Colloid Interface Sci. 1969, 3, 116-130. [CrossRef]

(C) 2017 by the authors. Licensee MDPI, Basel, Switzerland. This article is an open access article distributed under the terms and conditions of the Creative Commons Attribution (CC BY) license (http://creativecommons.org/licenses/by/4.0/). 